\title{
ENZYMATIC ANALYSIS IN Anopheles nuneztovari GABALDÓN (DIPTERA, CULICIDAE)
}

\author{
SCARPASSA, V. M. ${ }^{1}$ and TADEI, W. P. ${ }^{2}$ \\ 'Coordenação de Pesquisas em Entomologia, Instituto Nacional de Pesquisas da Amazônia, Avenida André Araujo, \\ 2936, CEP 69011-970, Manaus, AM, Brazil \\ ${ }^{2}$ Coordenação de Pesquisas em Ciências da Saúde, Instituto Nacional de Pesquisas da Amazônia, Avenida André \\ Araújo, 2936, CEP.: 69011-970, Manaus, AM, Brazil \\ Correspondence to: Vera Margarete Scarpassa, Coordenação de Pesquisas em Entomologia, Instituto Nacional de \\ Pesquisas da Amazônia, Avenida André Araujo, 2936, CEP 69011-970, Manaus, AM, Brazil, \\ e-mail: vera@inpa.gov.br
}

Received January 4, 1999 - Accepted March 27, 2000 - Distributed November 30, 2000

(With 2 figures)

\begin{abstract}
Enzymatic analysis in Anopheles nuneztovari was made using four populations from the Brazilian Amazon and two from Colombia. The enzymes ME and XDH presented a monomorphic locus in all of the studied populations. EST and LAP presented a higher number of loci. In EST, genetic variation was observed in the five loci; LAP presented four loci, with allec variation in two loci. In IDH, three activity regions were stained, with genetic variation for locus Idh-l in the Brazilian Amazon populations. A locus for MDH was observed, with genetic variation in the six populations. A region was verified for ACON, with four alleles in Sitronela and three in the other populations. PGM constituted one locus, with a high variability in the Brazilian Amazon populations. A locus was observed for 6-PGD with allelic variation in all of the populations with the exception of Tibú. Enzyme PGI presented two loci, both with genetic variability in the Tucuruí population. The enzyme $\alpha$-GPD showed an activity region with polymorphism in the Tucuruí, Tibú and Sitronela populations. The phenotypic variations detected for these enzymes suggest that four (EST, LAP, ACON and PGM) possess monomeric structures and five (IDH, MDH, 6-PGD, PGI and $\alpha$ GPD) dimeric structures in their proteins. These enzymes constitute in important markers to estimate variability and genetic divergence in natural populations of A. nuneztovari.
\end{abstract}

Key words: isozymes, electrophoretic profiles, genetic variation, neotropical anopheline, Amazonian.

\section{RESUMO}

Análise enzimática em Anopheles nuneztovari Gabaldón (Diptera, Culicidae)

Foi realizada análise enzimática em Anopheles nuneztovari em quatro populações da Amazônia, Brasil, e em duas da Colômbia. As enzimas ME e XDH mostraram um loco monomórfico em todas as populações estudadas. A EST e a LAP apresentaram maior número de locos. Na primeira, observouse variação genética nos cinco locos revelados; na segunda dos quatro locos, dois apresentaram variação alélica. $\mathrm{Na}$ IDH, três regiões de atividade foram reveladas, com variação genética para o loco Idh-1 em populações da Amazônia. Observou-se um loco para a MDH, com variação nas seis populações. Uma região foi verificada para ACON, com quatro alelos na população de Sitronela e três nas demais populações. A PGM consistiu de um loco, com variabilidade elevada nas populações da Amazônia. Um loco foi verificado para 6-PGD com variação alélica em todas as populações, exceto em Tibú. A enzima PGI apresentou dois locos, ambos com variação apenas na população de Tucuruí. A $\alpha$-GPD consistiu de uma região de atividade, com variação nas populações de Tucuruí, Tibú e Sitronela. A variação fenotípica detectada para estas enzimas sugere que quatro (EST, LAP, 
ACON e PGM) possuem estrutura monomérica e cinco (IDH, MDH, 6-PGD, PGI e $\alpha$-GPD), estrutura dimérica em suas proteínas. Essas enzimas constituem-se em importantes marcadores para estimar variabilidade e divergência genética em populações naturais de A. nuneztovari.

Palavras-chave: isoenzimas, perfis eletroforéticos, variação genética, anofelino neotropical, Amazônia.

\section{INTRODUCTION}

In Anopheles, Aedes and Culex geni, isozymes have been used in genetic variability analysis among populations within species, and also as genetic markers important in the sibling species separation, by diagnostic loci or by a combination of several loci that show differentiation (Narang \& Seawright, 1990). In anopheline mosquitoes, diagnostic loci are frequently used to separate morphologically similar species in several species complexes. The identification of these species becomes relevant, as it allows separation of members that are involved in human malaria transmission (Coluzzi, 1988). Thus, interpretation of electrophoretic profiles of different enzymatic systems is a basic necessity for these studies.

In this study, we interpreted the electrophoretic profiles of eleven enzymes in six populations of the human malaria vector Anopheles (Nyssorhynchus) nuneztovari, including the photos for each enzyme, the number of activity zones coded by different loci and their possible allelic variants. Population structure and genetic divergence among these populations were analyzed by Scarpassa et al. (1999).

\section{MATERIAL AND METHODS}

Samples of A. nuneztovari were collected at four sites in the Brazilian Amazon [km 206 of the BR-174 Highway (BR), Amazonas State $\left(1^{\circ} 16^{\prime} \mathrm{S}, 60^{\circ} 23^{\prime} \mathrm{W}\right)$; Puraquequara (PUR), Amazonas State $\left(3^{\circ} 6^{\prime} 7^{\prime} ' \mathrm{~S}, 60^{\circ} 10^{\prime} 30^{\prime \prime} \mathrm{W}\right)$; Tucuruí (TUC), Pará State $\left(3^{\circ} 42^{\prime} \mathrm{S}, 49^{\circ} 27^{\prime} \mathrm{W}\right)$; and Nova Mazagão (NOMA), Amapá State $\left(0^{\circ} 7^{\prime}\right.$ S, $\left.51^{\circ} 17^{\prime} \mathrm{W}\right)$ ], and two sites in Colombia [Tibú (TIBÚ), Norte de Santander Department ( $8^{\circ} 39^{\prime} \mathrm{N}$, $72^{\circ} 42^{\prime} \mathrm{W}$ ); and Sitronela (SIT), Valle Department $\left.\left(3^{\circ} 49^{\prime} \mathrm{N}, 77^{\circ} 4^{\prime} \mathrm{W}\right)\right]$. The specimens were captured when feeding on pigs, cattle, resting on stable walls or human biting. After captures, blood-fed mosquitoes were individually isolated in plastic cups for egg laying, according to Scarpassa \& Tadei (1990). Following oviposition and eclosion, the offspring $\left(\mathrm{F}_{1}\right)$ were reared until the $4^{\text {th }}$ instar larvae, pupae and adults, when they were frozen at $-70^{\circ} \mathrm{C}$, until analyzed. Fourth instar larvae were used in the analysis of ten enzymes, except for $\alpha$ glycerophosphate dehydrogenase ( $\alpha-G P D)$, for which adults were used. An average of 2-4 individuals from each progeny were employed. Electrophoresis was carried out in starch (12\%) and starch-agarose gels $(1 \%$ and $0.8 \%$, respectively). Buffer solutions and reactions mixtures were according to Harris \& Hopkinson (1976), Steiner \& Joslyn (1979) and Scarpassa et al. (1999).

The electrophoretic conditions used for each enzyme are showed in the Table 1. Identification of the specimens were done on eggs, adults and male genitalia (Cova-Garcia, 1961; Gorham et al., 1967; Savage, 1986). The denomination employed for loci and alleles was according to Manguin et al. (1995) and Scarpassa et al. (1999), frequently used in mosquitos, where the allele most common was considered as 100 .

\section{RESULTS AND DISCUSSION}

The electrophoretic patterns of the eleven enzymatic systems were analyzed: malic enzyme (ME, E.C.1.1.1.40), xanthine dehydrogenase (XDH, E.C.1.2.1.37), esterase (EST, E.C.3.1.1.1), leucine aminopeptidase (LAP, E.C.3.4.11.1), isocitrate dehydrogenase (IDH, E.C.1.1.1.42), malate dehydrogenase (MDH, E.C.1.1.1.37), aconitase (ACON, E.C.4.2.1.3), 6 phosphogluconate dehydrogenase (6-PGD, E.C.1.1.1.44), phosphoglucomutase (PGM, E.C.5.4.2.2), phosphoglucose isomerase (PGI, E.C.5.3.1.9) and $\alpha$ glycerophosphate dehydrogenase ( $\alpha$-GPD, E.C.1.1.1.8). The number of involved loci and their allelic variants of each enzyme are described below.

\section{Malic Enzyme and Xanthine Dehydrogenase}

The electrophoretic profiles of the ME and $\mathrm{XDH}$ enzymes presented one activity zone and they were monomorphic in the studied populations (Figs. 1A and B, Table 2). 
TABLE 1

Electrophoretic conditions used in the eleven enzymes of Anopheles nuneztovari.

\begin{tabular}{|c|c|c|c|c|c|}
\hline \multirow[t]{2}{*}{ Enzymes } & \multicolumn{2}{|c|}{ Buffer } & \multirow[t]{2}{*}{ Gel type } & \multirow{2}{*}{$\begin{array}{l}\text { Migration } \\
\text { time (hours) }\end{array}$} & \multirow[t]{2}{*}{$\mathrm{V} / \mathrm{cm}$} \\
\hline & Bridge & Gel & & & \\
\hline EST, LAP & $\begin{array}{l}0.3 \mathrm{M} \\
\text { Borate } \\
\text { pH } 8.0\end{array}$ & $\begin{array}{c}0.17-0.0023 \mathrm{M} \\
\text { Tris-citrate } \\
\text { pH } 8.0\end{array}$ & Starch & 12 & 1.7 \\
\hline $\mathrm{IDH}, \mathrm{ME}, \mathrm{MDH}$ & $\begin{array}{c}0.245-0.15 \mathrm{M} \\
\text { Phosphate-citrate } \mathrm{pH} \\
5.9\end{array}$ & $\begin{array}{c}\text { 1:40 dilution }(\mathrm{v}: \mathrm{v}) \\
\text { of the bridge } \\
\text { buffer }\end{array}$ & Starch & 15 & 2.6 \\
\hline ACON, 6-PGD & $\begin{array}{c}0.135-0.040 \mathrm{M} \\
\text { Tris-citrate } \\
\text { pH } 6.90\end{array}$ & $\begin{array}{c}0.009-0.003 \mathrm{M} \\
\text { Tris-citrate } \\
\text { pH } 7.10\end{array}$ & Starch & 16 & 2.3 \\
\hline PGM & $\begin{array}{l}0.22 \mathrm{M} \\
\text { TEMM } \\
\text { pH } 7.4\end{array}$ & $\begin{array}{c}1: 15 \text { dilution } \\
\text { (v:v) of the bridge } \\
\text { buffer }\end{array}$ & Starch-agarose & 5 & 4.8 \\
\hline PGI & $\begin{array}{l}0.22 \mathrm{M} \\
\text { TEMM } \\
\text { pH } 7.4\end{array}$ & $\begin{array}{c}1: 15 \text { dilution } \\
\text { (v:v) of the bridge } \\
\text { buffer }\end{array}$ & Starch & 16 & 2.3 \\
\hline$\alpha-G P D$ & $\begin{array}{c}0.1 \mathrm{M} \\
\text { Tris-phosphate } \\
\text { pH } 7.4\end{array}$ & $\begin{array}{c}1: 20 \text { dilution } \\
\text { (v:v) of the bridge } \\
\text { buffer }\end{array}$ & Starch & 16 & 2.6 \\
\hline $\mathrm{XDH}$ & $\begin{array}{c}0.036-0.194 \mathrm{M} \\
\text { Lithium-borate } \\
\text { pH } 8.25\end{array}$ & $\begin{array}{c}0.074-0.009 \mathrm{M} \\
\text { Tris-citrate } \\
\text { pH } 8.45\end{array}$ & Starch & 15 & 1.7 \\
\hline
\end{tabular}

Similar results were obtained in several species of the Nyssorhynchus subgenus (Narang et al., 1979; Hii et al., 1991; Narang et al., 1991).

For ME, however, one locus with two or more alleles was verified in the four species of $A$. quadrimaculatus complex (Narang et al., 1989), in A. deaneorum and A. marajoara (Narang et al., 1993) and in A. pseudopunctipennis (Manguin et al., 1995). Two loci with genetic variation were found in the A. punctulatus complex (Foley et al., 1995). Genetic variation was detected for XDH in at least one locus in A. aquasalis (Steiner et al., 1981), in the A. quadrimaculatus complex (Narang et al., 1989), in A. albimanus (Narang et al., 1991), and in A. deaneorum and A. marajoara (Narang et al., 1993).

\section{Esterase}

Analysis of the $4^{\text {th }}$ instar larvae presented an electrophoretic profile complex with five activity zones in the six populations. The allelic variants observed for all of these isozymes allow for the proposal that they are coded by independent loci: Est-1, Est-2, Est-3, Est-4 and Est-5. In the Est-
1 to Est-4 loci the number of alleles present cannot be quantified, due to overlapping of the alleles among these loci. Detailed analysis was possible only on the Est-5 locus (Fig. 1C). In the four Brazilian Amazon populations, five codominant alleles were observed, being the most frequents Est-5 ${ }_{109}, E s t-5_{106}$ and Est-5 ${ }_{100}$ (Table 2). The population from NOMA presented the highest number of genotype combinations, with 12 phenotypes. The two Colombian populations presented only two alleles Est-5 ${ }_{109}$ and Est-5 ${ }_{106}$. The Est-5 106 allele showed high frequency in both populations. The heterozygous individuals presented two bands, suggesting a monomeric structure for this isozyme.

Our data support previous studies, which indicate that esterase is the most variable enzyme in mosquitoes, as well as in other insects, small vertebrates and plants (Wagner \& Selander, 1974). In anopheline mosquitoes such as in A. albimanus of the six stained loci, four were polymorphic (Vedbrat \& Whitt, 1975), in A. aquasalis, five of the six stained loci presented genetic variation (Narang et al., 1979), in A. nuneztovari from Suriname and 
Venezuela, three of the five loci presented variation (Steiner et al., 1980), as well as three of the six loci in A. darlingi (Santos et al., 1996), and two of the four loci in A. albitarsis (Maia, 1997).

TABLE 2

Frequencies of alleles at sixteen loci of Anopheles nuneztovari.

\begin{tabular}{|c|c|c|c|c|c|c|c|}
\hline & & \multicolumn{6}{|c|}{ Population } \\
\hline Locus & Allele & BR & PUR & TUC & NOMA & TIBÚ & SIT \\
\hline \multirow[t]{7}{*}{ Pgm } & $\mathrm{n}$ & 141 & 158 & 52 & 136 & 85 & 85 \\
\hline & 113 & 0.039 & 0.013 & 0 & 0.026 & 0 & 0 \\
\hline & 108 & 0.429 & 0.516 & 0.019 & 0.371 & 0.265 & 0.412 \\
\hline & 100 & 0.362 & 0.263 & 0.875 & 0.445 & 0.735 & 0.588 \\
\hline & 94 & 0.149 & 0.196 & 0.096 & 0.011 & 0 & 0 \\
\hline & 91 & 0.021 & 0.013 & 0.010 & 0.121 & 0 & 0 \\
\hline & 89 & 0 & 0 & 0 & 0.026 & 0 & 0 \\
\hline \multirow[t]{4}{*}{$6 P g d$} & $\mathrm{n}$ & 130 & 124 & 89 & 67 & 64 & 62 \\
\hline & 108 & 0 & 0.012 & 0 & 0.007 & 0 & 0 \\
\hline & 100 & 0.988 & 0.988 & 0.983 & 0.985 & 1 & 0.952 \\
\hline & 92 & 0.012 & 0 & 0.017 & 0.007 & 0 & 0.048 \\
\hline \multirow[t]{5}{*}{ Acon } & $\mathrm{n}$ & 112 & 124 & 76 & 51 & 64 & 60 \\
\hline & 106 & 0 & 0 & 0 & 0 & 0.102 & 0.275 \\
\hline & 103 & 0 & 0.004 & 0 & 0.108 & 0.156 & 0.042 \\
\hline & 100 & 0.991 & 0.960 & 1 & 0.892 & 0.742 & 0.667 \\
\hline & 98 & 0.009 & 0.036 & 0 & 0 & 0 & 0.017 \\
\hline \multirow[t]{5}{*}{$M d h$} & $\mathrm{n}$ & 104 & 152 & 99 & 71 & 72 & 73 \\
\hline & 113 & 0 & 0.026 & 0.005 & 0.014 & 0 & 0 \\
\hline & 100 & 1 & 0.947 & 0.949 & 0.986 & 0.319 & 0.322 \\
\hline & 94 & 0 & 0.026 & 0.035 & 0 & 0.681 & 0.678 \\
\hline & 78 & 0 & 0 & 0.010 & 0 & 0 & 0 \\
\hline \multirow[t]{2}{*}{$I d h-1$} & $\mathrm{n}$ & 138 & 169 & 99 & 83 & 66 & 54 \\
\hline & 106 & 0.029 & 0.012 & 0.030 & 0.102 & 0 & 0 \\
\hline
\end{tabular}


TABLE 2 (Continued)

\begin{tabular}{|c|c|c|c|c|c|c|c|}
\hline \multirow[b]{2}{*}{ Locus } & \multirow[b]{2}{*}{ Allele } & \multicolumn{6}{|c|}{ Population } \\
\hline & & BR & PUR & TUC & NOMA & TIBÚ & SIT \\
\hline & 100 & 0.964 & 0.988 & 0.934 & 0.898 & 1 & 1 \\
\hline & 93 & 0.007 & 0 & 0.035 & 0 & 0 & 0 \\
\hline \multirow[t]{4}{*}{$\alpha G p d$} & $\mathrm{n}$ & 55 & 66 & 56 & 75 & 44 & 97 \\
\hline & 107 & 0 & 0 & 0.036 & 0 & 0 & 0 \\
\hline & 100 & 1 & 1 & 0.964 & 1 & 0.989 & 0.052 \\
\hline & 90 & 0 & 0 & 0 & 0 & 0.011 & 0.948 \\
\hline \multirow[t]{3}{*}{ Lap-1 } & $\mathrm{n}$ & 156 & 145 & 130 & 80 & 31 & 69 \\
\hline & 100 & 1 & 0.976 & 1 & 1 & 1 & 1 \\
\hline & 98 & 0 & 0.024 & 0 & 0 & 0 & 0 \\
\hline \multirow[t]{3}{*}{ Lap -5} & $\mathrm{n}$ & 160 & 147 & 21 & 120 & 87 & 72 \\
\hline & 100 & 1 & 1 & 0.857 & 0.967 & 0.937 & 0.938 \\
\hline & 98 & 0 & 0 & 0.143 & 0.033 & 0.063 & 0.063 \\
\hline \multirow[t]{6}{*}{ Est-5 } & $\mathrm{n}$ & 142 & 128 & 100 & 68 & 78 & 80 \\
\hline & 111 & 0.007 & 0.008 & 0.025 & 0.074 & 0 & 0 \\
\hline & 109 & 0.190 & 0.180 & 0.330 & 0.368 & 0.058 & 0.019 \\
\hline & 106 & 0.239 & 0.234 & 0.485 & 0.110 & 0.942 & 0.981 \\
\hline & 100 & 0.532 & 0.516 & 0.145 & 0.367 & 0 & 0 \\
\hline & 97 & 0.032 & 0.063 & 0.015 & 0.081 & 0 & 0 \\
\hline \multirow[t]{3}{*}{ Pgi-1 } & $\mathrm{n}$ & 73 & 123 & 28 & 75 & 69 & 69 \\
\hline & 100 & 1 & 1 & 0.911 & 1 & 1 & 1 \\
\hline & 96 & 0 & 0 & 0.089 & 0 & 0 & 0 \\
\hline \multirow[t]{2}{*}{$P g i-2$} & $\mathrm{n}$ & 65 & 78 & 84 & 75 & 69 & 69 \\
\hline & 110 & 0 & 0 & 0.024 & 0 & 0 & 0 \\
\hline
\end{tabular}


TABLE 2 (Continued)

\begin{tabular}{|c|c|c|c|c|c|c|c|}
\hline \multirow[b]{2}{*}{ Locus } & \multirow[b]{2}{*}{ Allele } & \multicolumn{6}{|c|}{ Population } \\
\hline & & BR & PUR & TUC & NOMA & TIBÚ & SIT \\
\hline & 100 & 1 & 1 & 0.952 & 1 & 1 & 1 \\
\hline & 93 & 0 & 0 & 0.024 & 0 & 0 & 0 \\
\hline \multirow[t]{2}{*}{ Lap-2 } & $\mathrm{n}$ & 161 & 151 & 181 & 125 & 102 & 86 \\
\hline & 100 & 1 & 1 & 1 & 1 & 1 & 1 \\
\hline \multirow[t]{2}{*}{ Lap-4 } & $\mathrm{n}$ & 159 & 148 & 182 & 126 & 103 & 85 \\
\hline & 100 & 1 & 1 & 1 & 1 & 1 & 1 \\
\hline \multirow[t]{2}{*}{$I d h-2$} & $\mathrm{n}$ & 110 & 130 & 72 & 68 & 66 & 54 \\
\hline & 100 & 1 & 1 & 1 & 1 & 1 & 1 \\
\hline \multirow[t]{2}{*}{$M e$} & $\mathrm{n}$ & 139 & 154 & 56 & 68 & 60 & 60 \\
\hline & 100 & 1 & 1 & 1 & 1 & 1 & 1 \\
\hline \multirow[t]{2}{*}{$X d h$} & $\mathrm{n}$ & 112 & 104 & 45 & 52 & 48 & 54 \\
\hline & 100 & 1 & 1 & 1 & 1 & 1 & 1 \\
\hline
\end{tabular}

BR = BR-174 Highway; PUR = Puraquequara; TUC = Tucuruí; NOMA = Nova Mazagão; TIBÚ = Tibú; and SIT = Sitronela.

Also, ontogenetic analysis of the A. nuneztovari population from Tucuruí, presented seven loci with genetic variation in six (Scarpassa, 1988). These results suggest that esterase isozymes are important markers for estimating genetic variability in natural populations of anopheline mosquitoes.

\section{Leucine Aminopeptidase}

Leucine aminopeptidase showed four electronegative activity zones in the six populations. Lap-1 and Lap-5 presented a weak coloration, and Lap-2 and Lap-4 were intensely colored (Fig. 1D). In this study, Lap-3 was not visualized because it is exclusive for pupa and adult stages (Scarpassa et al., 1992). The Lap-1 locus was monomorphic in all populations, except in the population from PUR, which showed two alleles, Lap- $1_{100}$ and Lap-1 ${ }_{98}$ (Table 2). Lap-2 and Lap-4 loci were monomorphic in all the populations. The Lap-5 locus showed two codominant alleles, being the Lap-5 ${ }_{100}$ allele fixed in the PUR, and it was more common in the populations from BR, TUC, NOMA, TIBÚ and SIT (Table 2). Two bands in the heterozygous individuals were verified, which allows to propose that the protein structure is monomeric. We also observed in the Lap-5 locus two additional bands in heterozygous individuals and exclusive of the population from TUC. This results suggests that the presence of these bands may be a consequence of post-translational changes. However, this hypothesis may be reinforced with additional studies. 

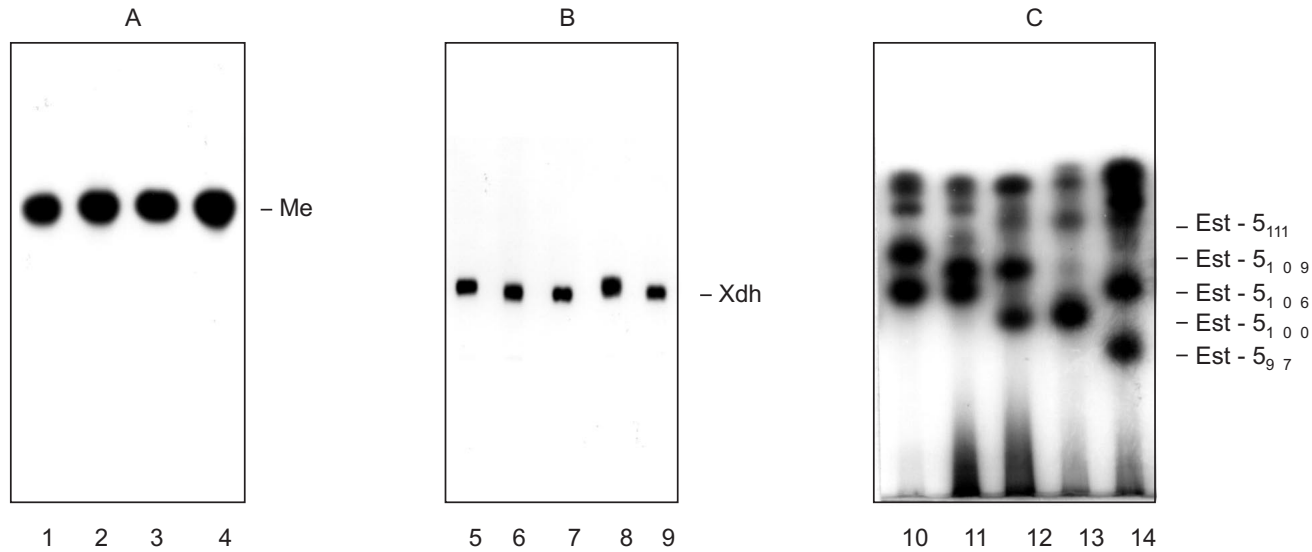

D

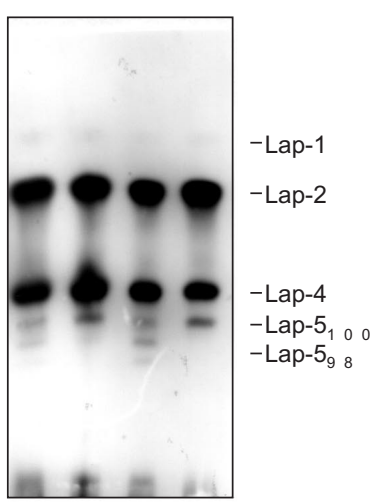

$\begin{array}{llll}15 & 16 & 17 & 18\end{array}$

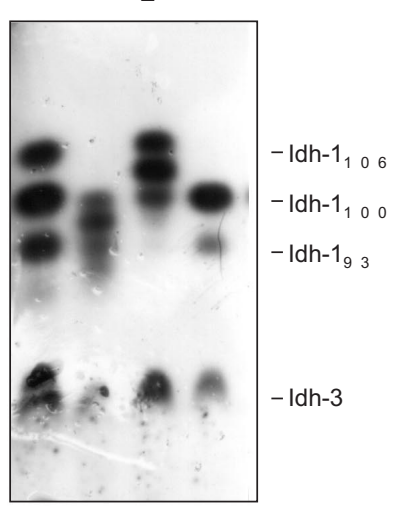

$\begin{array}{llll}19 & 20 & 21 & 22\end{array}$
$\mathrm{F}$

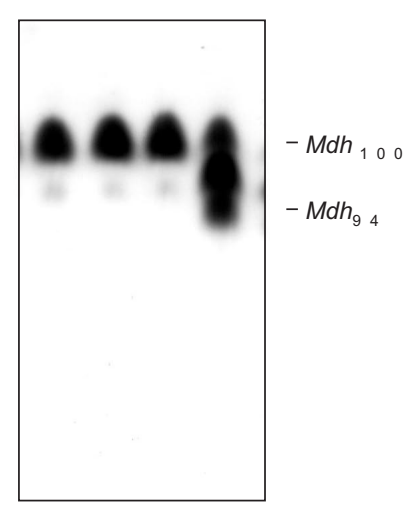

$\begin{array}{llll}23 & 24 & 25 & 26\end{array}$

Fig. 1 - Anopheles nuneztovari. A) Malic enzyme. Samples from PUR. B) Xanthine dehydrogenase. Samples from PUR. C) Esterase.

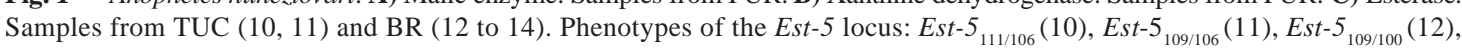
Est-5 ${ }_{100}(13)$, Est-5 ${ }_{106 / 97}(14)$. D) Leucine aminopeptidase. Samples from TUC. Phenotypes of the Lap-5 locus: Lap-5 $100 / 98$ (15, 17); Lap-5 ${ }_{100}(16,18)$. E) Isocitrate dehydrogenase. Samples from TUC. Phenotypes of the Idh-1 locus: Idh-1 $1_{106 / 93}(19), I_{d h-1}{ }_{100 /}$ ${ }_{93}(20), I d h-1_{106 / 100}(21), I d h-1_{100}(22)$. F) Malate dehydrogenase. Samples from TUC. Phenotypes of the $M d h$ locus: $M d h_{100}(23$ to 25$), M d h_{100 / 94}(26)$.

Low variability for this enzyme in A. nuneztovari, is in accordance with results found for others species of Neotropical anopheline, such as A. aquasalis (Narang et al., 1979), A. darlingi (Santos et al., 1996), A. oswaldoi (Scarpassa, V. N. 2, unpubl. data), among others. Agreeing with the above results, ontogenetic analysis in A. nuneztovari showed six loci with variation in only one (Scarpassa et al., 1992).

\section{Isocitrate Dehydrogenase}

Isocitrate dehydrogenase showed three electronegative activity zones in the six populations (Fig. 1E). Idh-1 presented allelic variation in the four Brazilian Amazon populations. This suggests that it is genetically controlled by the $I d h-l$ locus, with three codominant alleles: $I d h-I_{106}, I d h-I_{100}$ and $I d h-I_{93}$. The $I d h-I_{100}$ allele was the most com- 
mon in the Brazilian Amazon (Table 2). The combination of these alleles resulted in the following phenotypes: $I d h-1_{106 / 100}$ and $I d h-1_{100}$, detected in the populations from PUR and NOMA; Idh- $1_{106}$ ${ }_{100}, I d h-I_{100}$ and $I d h-I_{100 / 93}$, in the population from $\mathrm{BR}$; and Idh-1 ${ }_{106 / 100}, I d h-1_{106 / 93}, I d h-1_{100}$ and Idh$1_{100 / 93}$, in the population from TUC.

In the Colombian populations the $I d h-1_{100}$ allele was fixed. $I d h-2$ presented a weak intensity band, probably determined by one monomorphic locus in the six populations. Three bands in the heterozygous individuals suggest a dimeric protein structure. Idh-3, despite showing a strong intensity in coloration, included variable bands in its electrophoretic mobility. It was not possible to interpret the genetic mechanism involved for this zone.

Comparing these results with those obtained for other anophelines, it can be verified that only two loci have been described, with allelic variation occurring in at least one. Examples of this can be seen in A. stephensi (Van Driel et al., 1987), A. quadrimaculatus complex (Narang et al., 1989), A. albimanus (Narang et al., 1991), A. balabacensis (Hii et al., 1991), A. dirus complex (Green et al., 1992), A. darlingi (Santos et al., 1996). However, the Idh-3 observed in A. nuneztovari is probably a third locus detected for the first time in Neotropical anophelines.

\section{Malate Dehydrogenase}

Malate dehydrogenase showed an electronegative zone in all studied populations (Fig. 1F). This zone presented four codominant alleles: $M d h_{113}, M d h_{100}, M d h_{94}$ and $M d h_{78}$. The $M d h_{100}$ allele had frequencies over $94 \%$ in the populations from the Brazilian Amazon, while the $M d h_{113}$, and $M d h_{78}$ alleles were observed low frequencies in the PUR, TUC and NOMA populations. On the other hand, the $M d h_{94}$ allele was the most frequent in the populations from TIBÚ and SIT (Table 2). The heterozygous individuals presented three bands, suggesting a dimeric enzyme structure. During analysis a less anodic region was observed. Its intensity varied according to the activity of the $M d h$ locus's bands. We believe that the presence of this region may be due to an isozyme of secondary origin.

Similarly to A. nuneztovari, one or two loci have been revealed with genetic variation in at least one, as in the A. quadrimaculatus complex (Narang et al., 1989), A. minimus (Green et al., 1990), A. albimanus (Narang et al., 1991), A. balabacensis (Hii et al., 1991), A. pseudopunctipennis (Estrada-Franco et al., 1993; Manguin et al., 1995), and A. punctulatus complex (Foley et al., 1995), among others.

\section{Aconitase}

A single activity zone of aconitase was detected in the six studied populations (Fig. 2A). In the Brazilian Amazon populations, the Acon $_{100}$ allele was the most common, and Acon $_{103}$ and Acon $_{98}$ alleles were rare (Table 2). Elevated variation was verified in the SIT populatoin with four alleles: Acon $_{106}$, Acon $_{103}$, Acon $_{100}$ and Acon $_{98}$. In SIT the Acon ${ }_{106}$ and Acon $_{100}$ alleles were the most frequent; in TIBÚ were detected the first three. Acon ${ }_{103}$ and Acon $_{100}$ were the most common. The heterozygous individuals showed two bands, indicating that the protein may be monomeric in structure.

However, Fritz et al. (1995) found two loci for Aconitase in A. nuneztovari from Venezuela, using adults. It is possible that the Acon- 1 locus, detected by these authors, is the locus Acon in the present study. The differences between these two studies may be due to distinct ontogenetic patterns. In other anophelines, where adult individuals were analyzed, two loci were also revealed with genetic variation for the Acon- 1 locus, such as in the $A$. punctulatus complex (Foley et al., 1995) and in $A$. rangeli and $A$. trinkae (Fritz et al., 1995).

\section{6-Phosphogluconate Dehydrogenase}

6-Phosphogluconate dehydrogenase presented one zone, with bands of strong intensity (Fig. 2B). In populations from BR, TUC and NOMA the $6-P g d$ locus presented three alleles $6-P g d_{92}$, $6-P g d_{100}$ and $6-P g d_{108}$; in the population from PUR, the first two were observed; and in SIT, the last two, being the $6-P g d_{100}$ allele the most frequent (Table 2). In TIBU, this locus was monomorphic for the $6-P g d_{100}$ allele. Heterozygous individuals showed three bands, suggesting a dimeric protein structure. These results agree with a great part of the studies performed in Anopheles (Steiner et al., 1981; Narang et al., 1993; Fritz et al., 1995; Santos et 
A

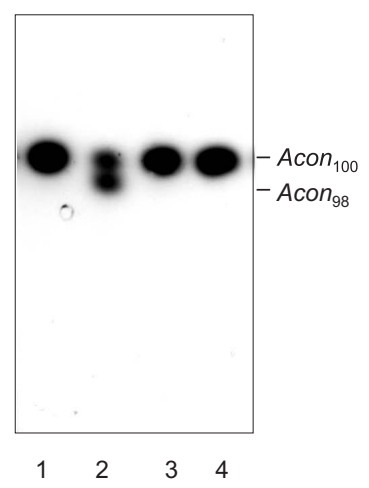

B

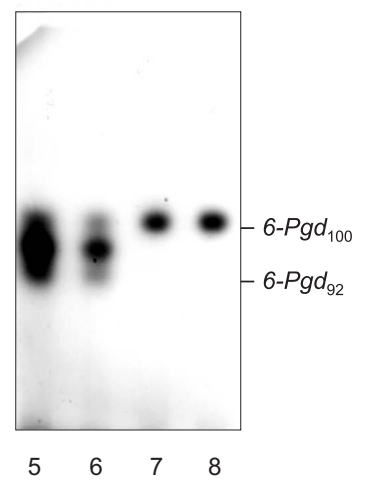

C

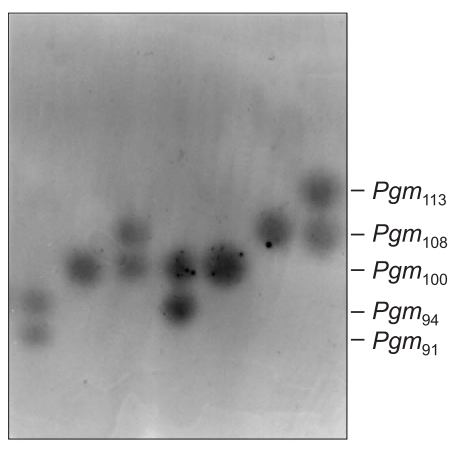

$\begin{array}{lllllll}9 & 10 & 11 & 12 & 13 & 14 & 15\end{array}$

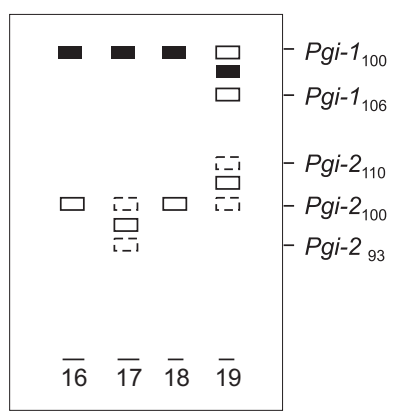

$E$

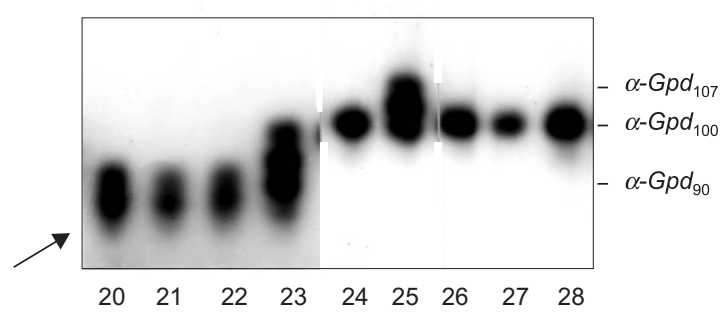

Fig. 2 - Anopheles nuneztovari. A) Aconitase. Samples from TUC. Phenotypes of the Acon locus: Acon 100 (1, 3, 4), Acon $_{100 / 98}(2)$. B) 6-Phosphogluconate dehydrogenase. Samples from TUC. Phenotypes of the 6-Pgd locus: 6-Pgd ${ }_{100 / 92}(5,6)$, 6-

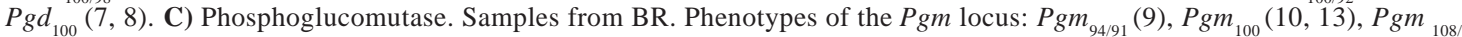
(11), $\operatorname{Pgm}_{100 / 94}$ (12), $\operatorname{Pgm}_{108}(14), \operatorname{Pgm}_{113 / 108}$ (15). D) Phosphoglucose isomerase. Samples from TUC. Phenotypes of the Pgi-

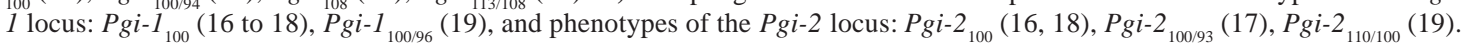
E) $\alpha$-Glycerophosphate dehydrogenase. Samples from SIT (20 to 23) and TUC (24 to 28). Phenotypes of the $\alpha$-Gpd locus: $\alpha$ $G p d_{90}(20$ to 22$), \alpha-G p d_{100 / 90}(23), \alpha-G p d_{100}(24,26$ to 28$), \alpha-G p d_{107 / 100}(25)$. The arrow points to the additional band.

al., 1996; Maia, 1997; among others). The exception is the A. quadrimaculatus complex, in which three loci were revealed with genetic variation in all of them (Narang et al., 1989).

\section{Phosphoglucomutase}

The phosphoglucomutase presented only one region (Fig. 2C). Genetic control for this zone was interpreted as depending on one locus $P g m$ with six codominant alleles: $P g m_{113}, P g m_{108}$, $P g m_{100}, \operatorname{Pgm}_{94}, \operatorname{Pgm}_{91}$ and $\operatorname{Pgm}_{89}$ (Table 2). The population from NOMA presented six alleles, while in three other populations from the Brazilian Amazon only the first five were detected. In the populations from TIBÚ and SIT only the $P_{g} m_{108}$ 
and $P g m_{100}$ alleles were verified. Heterozygous individuals showed two bands that indicate monomeric protein structure. The PGM enzyme has been extensively investigated in different insect groups, including the genus Anopheles. The results of this study are similar to those studies performed in other anopheline species, which described elevated genetic variation, and usually more than three alleles (Narang et al., 1989; 1993; Manguin et al., 1995).

\section{Phosphoglucose Isomerase}

Phosphoglucose isomerase presented two activity regions (Fig. 2D). It is probable that these zones are coded by two loci Pgi-1 and Pgi-2. Genetic variation was exclusive to the TUC population, with two alleles in the first locus and three in the second (Table 2). Heterozygous individuals presented a profile with three bands, allowing to propose a dimeric structure for the protein.

Distinct results were obtained for A. nuneztovari from Suriname and Venezuela. Steiner et al. (1980) described a monomorphic locus in adults possibly due to differences in the genic expression between larva and adult stage. One locus was also found in A. albitarsis (Maia, 1997), A. aquasalis (Steiner et al., 1981), A. quadrimaculatus complex (Narang \& Seawright, 1988), A. punctulatus complex (Foley et al., 1995), A. deaneorum and A. marajoara (Narang et al., 1993), and $A$. pseudopunctipennis (Manguin et al., 1995).

\section{$\alpha$-Glycerophosphate Dehydrogenase}

Analyzed in adults, the $\alpha$-GPD presented four electrophoretic profiles, interpreted as resulting from the presence of three alleles in the $\alpha$-Gpd locus: $G p d_{107}, G p d_{100}$ and $G p d_{90}$ (Fig. 2E; Table 2). The TUC population presented $\alpha$-Gpd $d_{107 /}$ ${ }_{100}$ and $\alpha-G p d_{100}$ phenotypes; the BR, PUR and NOMA populations, $\alpha-G p d_{100}$ phenotype; the TIBÚ population, $\alpha-G p d_{100}$ and $\alpha-G p d_{100 / 90}$ phenotypes; and the population from SIT $\alpha-G p d_{100}$, $\alpha-G p d_{100 / 90} \quad$ and $\alpha-G p d_{90}$ phenotypes. Heterozygous individuals showed three bands, suggesting a dimeric protein structure. The $\alpha$ $G p d_{90}$ phenotype, exclusive to the SIT population, presented one additional band, with slower migration in relation to the product of the $\alpha-G p d_{90}$ allele. We suggest that its presence would have originated by post synthesis changes, implicating structural modifications in the molecule that codes the allele $\alpha-G p d_{90}$ as it was absent in the unique homozygote individual found for the allele $\alpha-G p d_{100}$ (Scarpassa et al., 1996). Interesting, this additional band also was present in larvae, pupae and adults (Scarpassa et al., 1996). Interesting, this ontogenetic pattern differs from the Brazilian Amazon populations (Scarpassa \& Tadei, 1993).

Allelic variation in the $\alpha-G p d$ locus was also noted in populations of A. nuneztovari from Suriname (Steiner et al., 1980) and from Tucuruí (Scarpassa \& Tadei, 1993). However, in spite of the presence of genetic variation in populations of A. nuneztovari, one monomorphic locus has been observed in most Anopheles species (Narang et al., 1979; Lanzaro et al., 1995; Foley et al., 1995; among others).

The importance of the $\alpha$-GPD in the flight of the insects led to the investigation of this enzyme in various species, and the results showed that $\alpha$-GPD varies little (Johnson, 1974). The low frequency of heterozygous individuals observed in the $\alpha$-Gpd locus, indicates that most mutants are harmful (reviewed in Scarpassa \& Tadei, 1993). These conclusions are based on the premise that in insects this enzyme exerts an important metabolic role, producing energy for the maintenance of flight (O’Brien \& MacIntyre, 1972).

In summary, in this study a total of 21 loci was detected, 16 of them were analyzed due their better resolution and accuracy with the electrophoretic conditions employed. Of the 16 loci, five (Lap-2, Lap-4, Idh-2, Me and Xdh) were monomorphic in the six populations studied. The highest variability was found in the Pgm, Est-5 and Acon loci.

The data of this study are an important register of the electrophoretic profiles, including migration pattern in the gel, number of activity zones coded by different loci and their alleles of each enzyme studied in A. nuneztovari.

This makes it possible to compare them more accurately with patterns of other populations of $A$. nuneztovari, as well as of other anopheline species.

Acknowledgments - This research was supported by CNPq, by Fundação Banco do Brasil (FBB), and by Superintendência para o Desenvolvimento da Amazônia (SUDAM). The authors thank M. F. Suarez and S. Hurtado (Universidad del Valle, Cali, Colombia) and G. Alvarez and C. Viveros (Servício de la Erradicación de Malaria, Buenaventura, Colombia) for providing logistic support in the field in Colombia. 


\section{REFERENCES}

COLUZZI, M., 1988, Anopheline mosquitoes: genetics methods for species differentiation. In: W. H. Wernsdorfer \& I. McGregor (eds.), Malaria: Principles and Practise of Malariology. Edinburgh, Churchill Livingstone, pp. 411430.

COVA-GARCIA, P., 1961, Notas sobre los anofelinos de Venezuela y su identificación. Ed. Grafos, Caracas.

ESTRADA-FRANCO, J. G., LANZARO, G. C., WALKER-ABBEY, A., ROMANS, P., GALVAN-SANCHES, C., CESPEDES, J. L., VARGAS-SAGARNAGA, R., LAUGHINGHOUSE, A. \& COLUMBUS, I., 1993, Characterization of Anopheles pseudopuntipennis sensu latu from three countries of neotropical America from variation in allozymes and ribosomal DNA. Am. J. Trop. Med. Hyg., 49(6): 735-745

FOLEY, D. H., COOPER, R. D. \& BRYAN, J. H., 1995, A new species within the Anopheles punctulatus complex in western province, Papua, New Guinea. J. Am. Mosq. Control Assoc., 11(1): 122-127.

FRITZ, G. N., BERMUDEZ, H. \& SEAWRIGHT, J., 1995, Genetic differentiation and diagnostic loci of Anopheles nuneztovari, A. trinkae, and A. rangeli (Diptera: Culicidae). J. Med. Entomol., 32(5): 663-672.

GORHAM, J. R., STOJANOVICH, J. C. \& SCOTT, H. G., 1967, Illustrated Keys to the Anopheline Mosquitoes of Eastern South America. Centers for Disease Control, U. S. Department of Health, Education and Welfare, Public Health Service, Atlanta, GA.

GREEN, C. A., GASS, R. F. \& MUNSTERMANN, L. E., 1990, Population-genetic evidence for two species in Anopheles minimus in Thailand. Med. Veter. Entomol., 4: 25-34.

GREEN, C. A., MUNSTERMAnN, L. E., TAN, S. G., PANYIM, S. \& BAIMAI, V., 1992, Population genetic evidence for species A, B, C and D of the Anopheles dirus complex in Thailand and enzyme electromorphs for their identification. Med. Veter. Entomol., 6: 29-36.

HARRIS, H. \& HOPKINSON, D. A., 1976, Handbook of Enzyme Electrophoresis in Human Genetics. North-Holland, Amsterdam.

HII, J. L. K., CHEW, M., SANG, V. Y., MUNSTERMANN, L. E., TA, S. G., PANYIM, S. \& YASOTHORNSRIKUL, S., 1991, Population genetic analysis of host seeking and resting behaviors in the malaria vector, Anopheles balabacensis (Diptera: Culicidae). J. Med. Entomol., 28(5): 675-684.

JOHNSON, G. B., 1974, Enzyme polymorphism and metabolism. Science, 184: 28-37.

LANZARO, G. C., ZHENG, L., TOURÉ, Y. T., TRAORE, S. F., KAFATOS, F. C. \& VERNICK, K. D., 1995, Microsatellite DNA and isozyme variability in a West African population of Anopheles gambiae. Insect Mol. Biol., 4(2): 105-112.
MAIA, J. F., 1997, Variabilidade genética em populações naturais de Anopheles (Nyssorhynchus) albitarsis LynchArribálzaga, 1878 (Diptera: Culicidae). Master's thesis. INPA/UFAM. Manaus, Amazonas. 118p.

MANGUIN, S., ROBERTS, D. R., PEYTON, E. L., FERNANDEZ-SALAS, I., BARRETO, M., LOAYZA, R. F., SPINOLA, R. E., GRANAOU, R. M. \& RODRIGUES, M. H., 1995, Biochemical systematics and population genetic structure of Anopheles pseudopunctipennis, vector of malaria in Central and South America. Am. J. Trop. Med. Hyg., 53(4): 362-377.

NARANG, S. K. \& SEAWRIGHT, J. A., 1988, Electrophoretic method for recognition of sibling species of anopheline mosquitoes a practical approach. Florida Entomol., 71(3): 303-311.

NARANG, S. K. \& SEAWRIGHT, J. A., 1990, Genetic differentiation among members of species complexes in anopheline mosquitoes (Diptera: Culicidae). In: R. C. Sobti \& G. Obe (eds.), Eukaryotic Chromosomes. Structural and Functional Aspects. Norosa Publishing House, pp. 59-96.

NARANG, S. K., KLEIN, T. A., PERERA, O. P., LIMA, J. B. \& TANG, A. T., 1993, Genetic evidence for the existence of cryptic species in the Anopheles albitarsis complex in Brasil: allozymes and mitochondrial DNA restriction fragment lenght polymorphisms. Biochem. Genet., 31(1-2): $97-112$.

NARANG, S. K., KITZMILLER, J. B., GALLER, R., RIOS, R. I. \& NARANG, N., 1979, Genética de populações de anofelinos. III. Análise eletroforética de Anopheles aquasalis (Diptera: Culicidae). Rev. Brasil. Pesq. Med. Biol., 12(4-5): 303-309.

NARANG, S. K., SEAWRIGHT, J. A. \& SUAREZ, M. F., 1991, Genetic structure of natural populations of Anopheles albimanus in Colombia. J. Am. Mosq. Control Assoc., 7(3): 437-445.

NARANG, S. K., TONIOLO, S. K., SEAWRIGHT, J. A. \& KAISER, P. E., 1989, Genetic differentiation among sibling species A, B and C of the Anopheles quadrimaculatus complex (Diptera: Culicidae). Ann. Entomol. Soc. Am., 82(4): 508-515.

O'BRIEN, S. J. \& MACINTYRE, R. J., 1972, The $\propto$-Glycerophosphate cycle in Drosophila melanogaster. I. Biochemical and developmental aspects. Biochem. Genet., 7: $141-161$

SANTOS, J. M. M., TADEI, W. P. \& CONTEL, E. P. B., 1996, Electrophoretic analysis of 11 enzymes in natural populations of Anopheles (N.) darlingi Root, 1926 (Diptera: Culicidae) in the Amazon region. Acta Amaz., 26(1-2): 97-114.

SAVAGE, H. M., 1986, Identification and location of the holotype and paratypes of Anopheles (Nyssorhynchus) nuneztovari Gabaldón (Diptera: Culicidae). Mosq. Syst., 18(3-4): 279-283. 
SCARPASSA, V. M., 1988, Estudo do ciclo biológico e de isoenzimas na ontogênese de Anopheles (Nyssorhynchus) nuneztovari Gabaldón, 1940 (Diptera: Culicidae). Master's thesis. INPA/UFAM, Manaus, Amazonas, 172p.

SCARPASSA, V. M. \& TADEI, W. P., 1990, Biologia de Anofelinos Amazônicos. XIII. Estudo do ciclo biológico de Anopheles nuneztovari (Diptera: Culicidae). Acta Amaz., 20(único): 95-117.

SCARPASSA, V. M. \& TADEI, W. P., 1993, Biology of Amazonian Anophelines. XIX. $\alpha$-Glycerophosphate dehydrogenase in Anopheles nuneztovari (Diptera: Culicidae): ontogeny and genetic variation. Brazil. J. Genet., 16(2): 297-306.

SCARPASSA, V. M., TADEI, W. P. \& CONTEL, E. P. B., 1992, Biologia de Anofelinos Amazônicos. XV. Leucina aminopeptidase em Anopheles (Nyssorhynchus) nuneztovari: ontogenia e variação genética. Acta Amaz., 22(2): 229-238.

SCARPASSA, V. M., TADEI, W. P. \& SUAREZ, M. F., 1996, Allozyme differentiation among allopatric populations of Anopheles nuneztovari (Diptera: Culicidae). Brazil. J. Genet., 19(2): 265-269.

SCARPASSA, V. M., TADEI, W. P. \& SUAREZ, M. F., 1999, Population structure and genetic divergence in Anopheles nuneztovari (Diptera: Culicidae) from Brazil and Colombia. Am. J. Trop. Med. Hyg., 60(6): 1010-1018.
STEINER, W. W. M. \& JOSLYN, D. J., 1979, Electrophoretic techniques for the genetic study of mosquitoes. Mosq. News, 39(1): 35-54.

STEINER, W. W. M., KITZMILLER, J. B. \& OSTERBUR, D. L., 1980, Gene differentiation in chromosome races of Anopheles nuneztovari Gabaldón. Mosq. Syst., 12(3): 306-319.

STEINER, W. W. M., KITZMILLER, J. B. \& OSTERBUR, D.L., 1981, On the genetic identity and evolution of the malaria vectors Anopheles aquasalis Curry and Anopheles emilianus Komp. In: R. Pal, J. B. Kitzmiller \& T. Kanda (eds.), Cytogenetics and Genetics of Vectors. Elsevier Science, Publishing Company INC., New York, pp. 75-90.

VAN DRIEL, J. W., SLUITERS, J. F. \& VAN DER KAAY, H. J., 1987, Allozyme variation in Anopheles stephensi Liston from Pakistan (Diptera: Culicidae). Biochem. Genet., 25(11-12): 789-802.

VEDBRAT, S. S. \& WHITT, G. S., 1975, Isozyme of the mosquitoes Anopheles albimanus. In: Isozymes III - Developmental Biology. C. L. Markert Academic Press, New York, San Francisco, London, pp. 131-143.

WAGNER, R. \& SELANDER, R. K., 1974, Isozymes insects and their significance. Ann. Rev. Entomol., 19: 117-138. 